UDC $81 ' 42$ : 82-1 : 811.111

DOI https://doi.org/10.32841/2409-1154.2019.43.3.6

\author{
Moskvichova O. A., \\ CSc. (Philology), \\ Associate Professor at the Department of the English Language and the Methodology of Teaching \\ Kherson State University
}

\title{
THE FRACTAL POETICAL MODEL OF THE WORLD IN THE LINGUISTIC AND COGNITIVE ILLUMINATION
}

Summary. The article is dedicated to the illumination of the methodology of the modelling of the fractal poetical model of the world as the construct that consists from segments of micro- and macro-levels. The complexity of the fractal poetical model of the world is explained by the net of the conceptual senses of the frame mode and the integrated mode, their fractal self-similarity, conceptual and semantic approximations and deviations.

The article is dedicated to the investigation of the specificity of the reproduction of the reality in the fractal poetical model of the world on the basis of the British poetry of the XIX-XXI ${ }^{\text {st }}$ centuries with the help of the linguistic, of the poetical analysis of the lexical and the semantic tropes as the verbal means of the actualization of cognitive processes of the formation of the fractal poetical model of the world and the outlining of the axiological sense that is specific for the cognitive style of poets of the British romantic, the modern and the postmodern periods by means of linguistic, cognitive, poetic analyseses of the above mentioned tropes. The analyses comprises the usage of the cognitive and the discourse strategies of the interpretation of the deepest sense of the fractal poetical model of the world, such as: the reconstruction of the axiological literary concepts as elements of the fractal poetical model of the world, the modelling of the conceptual tropes as the cognitive basis of the formation and of the designing of the fractal poetical model of the world and the modelling of conceptual blends and frames as emergent cognitive structures of the embodied understanding in the poetics of the British romantic, the modern and the postmodern periods. The study presents the results of the multidisciplinary investigation of the modelling of the fractal poetical model of the world representing the peculiar scientific research of the author. The information presented in the article is the polydisciplinary combining the cognitive linguistics, the cognitive poetics and the mathematics with the fractal geometry.

Key words: literary concept, conceptual tropes, the fractal, fractal poetical model of the world, the attractor, microsegments of the fractal poetical model of the world, macrosegments of the fractal poetical model of the world, net of the conceptual senses of the frame mode and the integrated mode of the fractal poetical model of the world.

To see a World in a grain of sand, And a Heaven in a wild flower, Hold Infinity in the palm of your hand, And Eternity in an hour.

W. Blake "Auguries of Innocence" [5, p. 41]

Introduction. In the mathematics, in the computer science, in the fractal geometry, in the theory of systems, and in the synergetics 'the fractal' (from the Latin 'fractus' - 'to break, to destroy') - is identified as the object that is characterized by the fractional structure having the hierarchical level of the organization; as the endless geometrical figure every fragment of which is repeated in the reduced scale [2]. In the academic scientific world the leading role in the generation of the theory of fractals belongs to the mathematics because fractals have been identified by the mathematician Benoit B. Mandelbrot in his scientific research "The Fractal Geometry of Nature" [6]. Benoit B. Mandelbrot generated fractals by means of the mathematical and computer calculations and the researches of the coastline of Great Britain [6]. Fractals have been investigated deeply in the mathematics but this term belongs also to the sphere of the synergetics, the science that comprises the physics and the mathematics, and has been integrated into the linguistics being the interdisciplinary direction of the scientific researches in the aspect of which are investigated processes of the transition from the chaos to the order and vice versa in the open nonlinear spheres of the different nature [3]. In the article we are served by the dominant role of the exploration of the fractality in the mathematics because in the process of the constructing of the fractal poetical model of the world we rely on the postulates of the mathematical modelling of fractals.

The aim of the article is to describe the process of the modelling of the fractal poetical model of the world in the linguistic and the cognitive aspects on the basis of the British poetry of the XIX - XXI ${ }^{\text {st }}$ centuries.

The achievement of the aim involves the following tasks:

- to develop the complex methodology of the constructing of the fractal poetical model of the world based on the methodology of the cognitive linguistics, of the cognitive poetics, of the mathematics, of the fractal geometry with the consideration of the actuality of the illumination of the notion "the fractal" in the modern scientific paradigm;

- to reveal the segments of the fractal poetical model of the world based on the investigation of the ability of the modelling of the fractal poetical model of the world on the basis of the British poetry of the XIX - XXI ${ }^{\text {st }}$ centuries;

- to construct micro- and macrosegments of the fractal poetical model of the world with the linguistic and the cognitive aspects stating the hierarchical peculiarities of the literary concepts and the conceptual tropes fulfilling the mentioned segments;

- to arrange the typology of the conceptual and the sense approximations and deviations in the fractal poetical model of the world;

- to outline the ability of the fractal poetical model of the world to be developed into the net of the conceptual senses of the frame mode and the integrated mode of the fractal poetical model of the world. 
The hypothesis of the investigation is outlined by the ability of the modelling of the fractal poetical model of the world in the linguistic and the cognitive perspective through the prism of the mathematics and the fractal geometry. Literary concepts [7] and conceptual tropes are elements of micro- and macrosegments of the fractal poetical model of the world that could be developed into the net of the conceptual senses of the frame mode and the integrated mode of the fractal poetical model of the world. The present paper is the result of the doctoral scientific investigation of the author on the title "The fractal poetical model of the world in the linguistic and the cognitive survey (on the material of the British poetry of the XIXXXI" centuries)". The information presented in the article has never been outlined before and it has never been represented in the world linguistics by other linguists. The results of the investigation, presented in the paper, are developed by the author and are based on the doctoral dissertation thus they are new and innovative because the identical scientific researches have never been done in different scientific and linguistic paradigms before. That's why in the references are given a few literary sources because in the paper are presented the own scientific conclusions and considerations of the author.

\section{The material of the investigation and methods}

The material of the investigation is based on the British poetry of the XIX - XXI ${ }^{\text {st }}$ centuries in the total amount of 3628 poetical texts (4832 pages). For the illustration of the design of the fractal poetical model of the world have been chosen the brightest examples (490 poetical texts on 267 pages).

The methodology of the modelling of the fractal poetical model of the world is polydisciplinary conditioned by the combination of the interpretational, the textual, the descriptive, the semantic, the component, the linguistic, the stylistic, the cognitive, the poetical, the mathematical, the fractal, the geometrical methodology.

The methodology of the linguistic and the poetical analysis is represented by the interpretational, the textual, the descriptive, the semantic, the component, the linguistic and the stylistic methods. Methods of the cognitive linguistics and the cognitive poetics are outlined by the methodology of the reconstruction and the identification of the literary concepts and the conceptual tropes. The methodology of the mathematics and the fractal geometry is actual in the paper to model the fractal poetical model of the world with the actuality of the quantitative calculation of the results of the investigation.

\section{The discussion and results}

The revealing of fractals in the modern scientific paradigm

The founder of the theory of the fractality Benoit B. Mandelbrot has identified the term 'the fractal' from the Latin words 'frangere' ('to break') and 'fractus' ('ruptured, discrete, fractional'). The word is identical to the English 'fracture' ('the rapture') and 'fraction' ('the fraction'). Except the meaning 'fractional' (in words 'the fraction' and 'the refraction') the word 'fractus' means 'the wrong-shaped' [2]. Thus, Benoit B. Mandelbrot has modeled the definition of the identified by him term 'the fractal' as for the algorithm and the association from the English 'FRACTionAL'. Even graphically Benoit B. Mandelbrot has written the word 'FRACTAL' from 'FRACTionAL' by means of capital letters in the way the cognitive scientists write identified and verbalized concepts. The conceptual sphere in the field of the cognitive linguistics is graphically represented by the linguists in the similar way to the Circular Apollo Fractal (e.g., (Fig. 1)). Thus, we surmise the existence of the connection between the cognitive linguistics and the fractional mathematical theory in the graphical way.

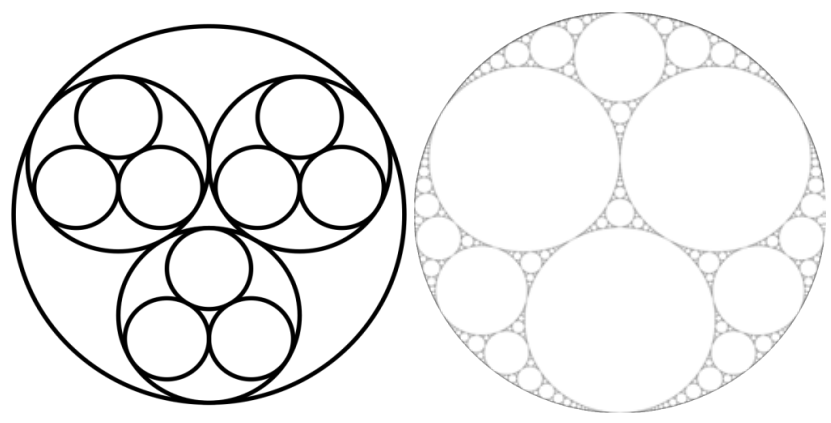

Figure 1. The Circular Apollo Fractals (after Mandelbrot 1982)

Fractals or the mathematical and the geometrical monsters have changed the mathematics of the end of the $\mathrm{XX}^{\text {th }}$ century and after their multidisciplinary integration into different scientific spheres lots of terms and forms have been identified by the scientists in the fractal and in the mathematical way. Benoit B. Mandelbrot has summarized different types of fractals, has identified the ways of the fractional computer calculation that has been integrated into the modern fractional computer graphics (e.g., (Fig. 2)).

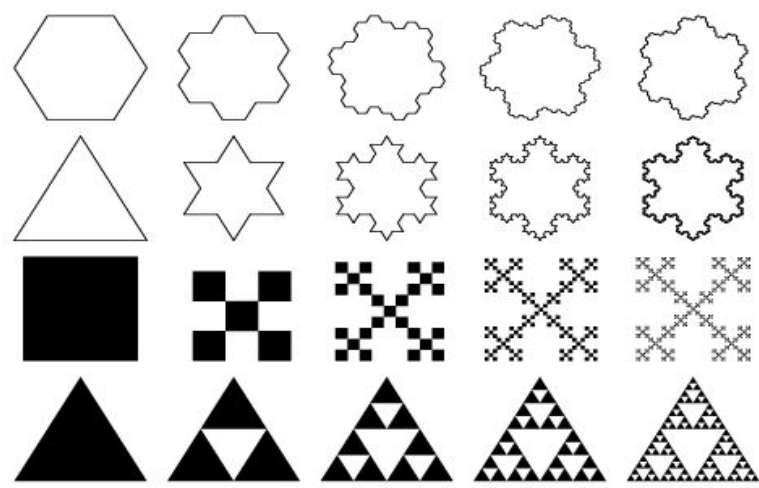

Figure 2. Types of fractals (after Mandelbrot 1982)

Benoit B. Mandelbrot has stated that every self-similar fractal element is never-ending because structurally every fractal consists from the smallest or the fractional elements the modelling of which is ruled by the previous elements of the fractal. The fractal is the self-similar and the never-ending unity, the connection between elements of which is determined by the connection between all the elements of the fractal. The construction of the fractal is strict and mathematically determined because every small element of the fractal is the simplified version of the whole fractal. The process of the modelling of the fractal is ruled by the repeated repetition of the analogical mathematical operations - iterations. Fractal iterations are recursive, the final stage of the previous element of the fractal is the beginning of the new stage of the fractal modelling - the iterational fractal process. The fractal modelling is the endless process because fractals have the beginning but don't have the ending and the final stage of the modelling [3].

The modelling of the fractal poetical model of the world

Extrapolating the methodology of the linguistic, the poetical, the cognitive analysises of the poetry and considering the results 
of the fractal modelling in the mathematics, in the fractal geometry, in the synergetics, in the theory of systems we propose the methodology of the modelling of the fractal poetical model of the world on the basis of the British poetry of the XIX$\mathrm{XXI}^{\mathrm{st}}$ centuries in the linguistic and in the cognitive perspectives.

Thus, the fractal poetical model of the world is characterized by the complex structure, the starting point of it's constructing is the strange / the circular / the cyclic fractal attractor (from the Latin 'attrahere' - 'to attract'; from the English 'to attract') [2]. The fractal attractor is the starting point of the fractal modelling that is stable and attracts to itself all the trajectory of the whole fractal system or the fractal model. Structurally, in the aspect of the fractal geometrical modelling, the fractal attractor comprises from the central node around which, in the spiral form, are pulverized trajectories of the fractal that never intersect and are concentrated around the central node of the attractor [2]. The strange fractal attractor in the fractal modelling is the trajectory of the fractal orbit that makes possible the fractal modelling to get started in such a way: 'the central node of the strange fractal attractor $\rightarrow$ the cycle $\rightarrow$ the fractal' (e.g., (Fig. 3)).
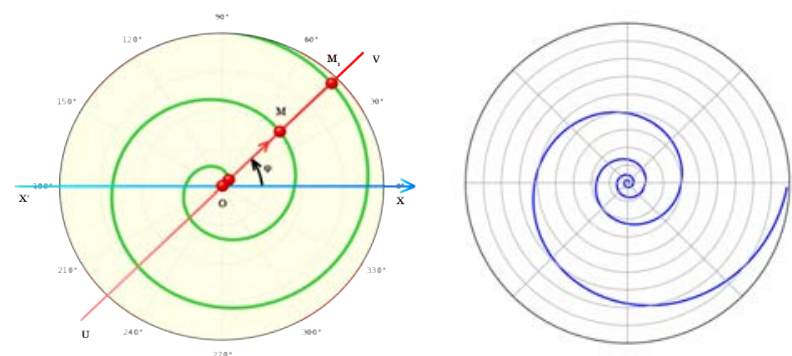

Figure 3. The trajectory of the fractal modelling from the central node of the strange fractal attractor to the cycle and to the fractal (after Деменок)

Integrating the theoretical aspects of the fractal modelling and taking into consideration the actuality of the term 'the strange fractal attractor' in the aspect of the fractal constructing while the modelling of the fractal poetical model of the world we propose to understand under the central node of the attractor the literary concept or literary concepts [7] that are identified by us in the British poetry of the XIX-XXI ${ }^{\mathrm{st}}$ centuries. The literary concept in the cognitive linguistics and in the cognitive poetics is the basic element of the fractal conceptual model of the world that includes linguistic and extra-linguistic aspects determined by historical and cultural traditions of the romantic, of the modern and of the postmodern periods in Great Britain [7].

The central node of the fractal poetical model of the world is the literary concept / literary concepts. According to the trajectory of the orbit of the strange fractal attractor the dynamics of the fractal modelling of the poetical model of the world we outline in such an order: literary concepts $\rightarrow$ the basic conceptual tropes (the conceptual metaphor, the conceptual metonymy, the conceptual oxymoron, the conceptual metamorphosis [4]) $\rightarrow$ the frame mode of the fractal poetical model of the world (frames) $\rightarrow$ the integrated mode of the fractal poetical model of the world (emergent conceptual blends) (e.g., (Fig. 4)):

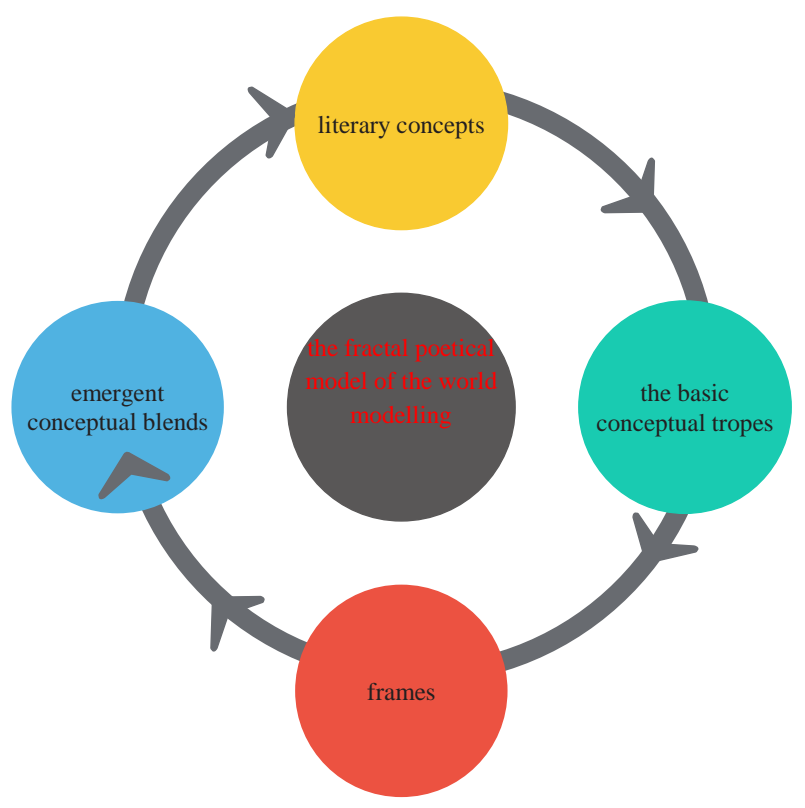

\section{Figure 4. The trajectory of the orbit of the strange fractal attractor as the basis of the fractal poetical model of the world modelling}

In the article is presented the information about the identification of the literary concepts and the basic conceptual tropes in the British poetry of the XIX-XXI ${ }^{\text {st }}$ centuries. The frame and the integrated modes of the fractal poetical model of the world will be represented in the next publications of the author of the article.

The realization of the fractal poetical model of the world in the British poetry ofthe romantic, of the modernand of the postmodern periods

The deep nature of the fractal poetical model of the world is determined by it's complicated linguistic and cognitive aspects that are explained by the combination in the fractal poetical model of the world micro-segments (literary concepts), macro-segments (basic conceptual tropes), frames and the emergent conceptual blends in one fractal unity. We define the fractal poetical model of the world as the complex linguistic, cognitive and fractal construct that comprises from segments modelled according to the iterational and integrated methodology of the linguistic, of the poetical, of the cognitive analysises with the deployment into the fractal net of the conceptual senses filled with frames and conceptual blends.

In the cognitive linguistics has been proved that the fractal 'iteration' (from the Latin 'iteration' - 'to repeat') is the process of the multiple repetition of the analogous structure or the step as for the analogy with the previous repetitive operation. The fractal 'recursion' (from the Latin 'recursiõ'- 'the returning') - the process of the repetition according to the certain algorithm or the formula when the starting cycle is the result of the previous cycle. The fractal self-similarity is the fractal peculiarity of the whole fractal system in which the structural organization of an element is repeated completely or partially according to the structure of other elements of the whole fractal system [1].

In the article we propose the fractal modelling of the fractal poetical model of the world based on the computer fractal modelling of the fundamental fractal - the Mandelbrot Fractal. But our investigation is added by the linguistic and the cognitive 
aspects of the fractal poetical model of the world based on the results of the scientific research on the basis of the British poetry of the XIX-XXI ${ }^{\text {st }}$ centuries from the point of the cognitive linguistics and the cognitive poetics. In such a way our investigation is multidisciplinary or the subdisciplinary combining the fractal theory in the mathematics and in the fractal geometry integrated into the sphere of the cognitive linguistics and of the cognitive poetics.

We have stated that the starting point of the modelling of the fractal poetical model of the world is the literary concept or literary concepts identified by us in the British poetry of the XIXXXIt centuries. The hierarchy of the verbalized literary concepts is congregated by us into the micro-segment of the fractal poetical model of the world. We design the micro-segment of the fractal poetical model of the world on the basis of the graphic modelling of the Mandelbrot Fractal that consists from three concentric circles. The main circle of the mentioned fractal is the main cardioid and the additional circles are the copies of the main cardioid circle. The number of additional circles may be endless (e.g., (Fig. 5)).

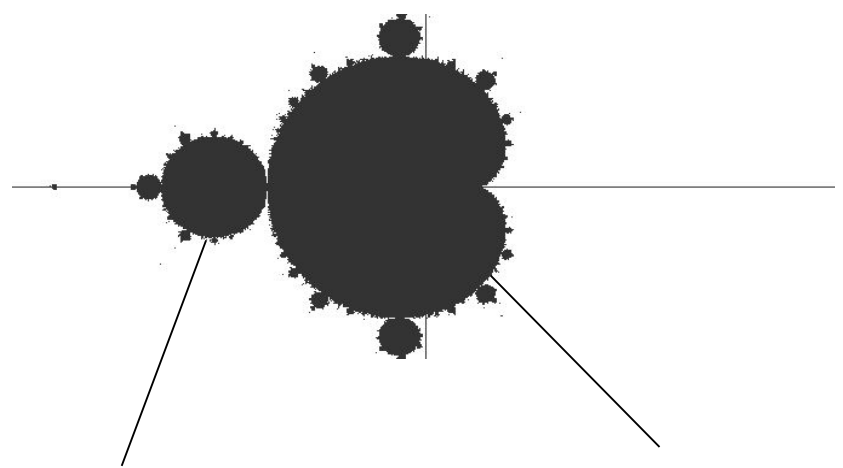

additional circles

the main cardioid circle

Figure 5. The graphic modelling and the structure of the Mandelbrot Fractal (after Mandelbrot 1982)

According to such a graphic design of the structure of the Mandelbrot Fractal we model the micro-segment of the fractal poetical model of the world that is impregnated by the identified by us literary concepts on the basis of the British poetry of the XIX$\mathrm{XXI}^{\text {st }}$ centuries. The main cardioid circle of the micro-segment of the fractal poetical model of the world (1) is the presentive and the sensual and is impregnated by the aptly identified literary concepts in the British poetry of the XIX-XXI ${ }^{\text {st }}$ centuries. The first additional circle of the fractal micro-segment of the fractal poetical model of the world (2) is denominated by us the typology of the conceptual and the semantic approximations on the microlevel of the micro-segment and is nominated by us the imaginative and the associative circle. This circle we impregnate by the literary concepts containing the information of the associative type. The next additional circle (3) is the circle of the conceptual and the semantic deviations and is impregnated by rare literary concepts and is identified by us as the semantic circle (e.g., (Fig. 6)).

In the analogical way we design the macro-segment of the fractal poetical model of the world that is repleted by the reconstructed by us conceptual tropes (the conceptual metaphor, the conceptual metonymy, the conceptual oxymoron, the conceptual metamorphosis [4]) (e.g., (Fig. 7)).

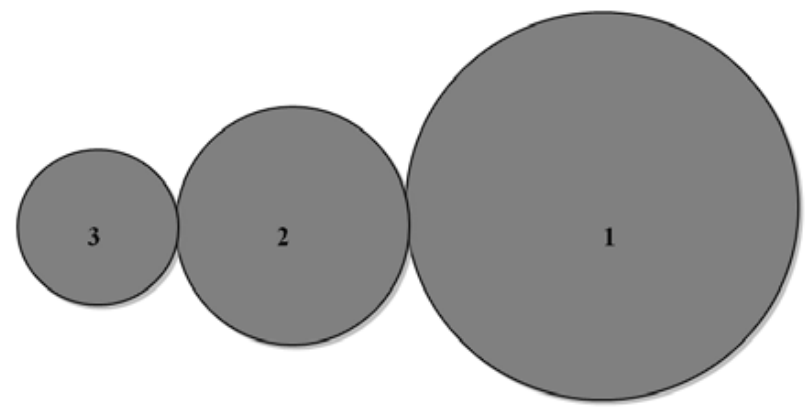

Figure 6. The fractal modelling of the micro-segments of the fractal poetical model of the world

( 1 - the presentive and the sensual micro-segment of the typology of the fractal iterations of the self-similar literary concepts; 2 - the conceptual and the semantic microsegment of the typology of the conceptual and the semantic approximations; 3 - the semantic micro-segment of the typology of the conceptual and the semantic deviations)

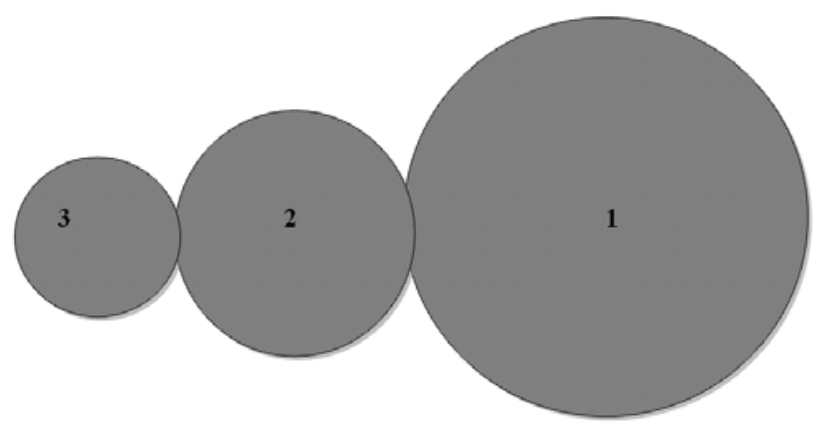

Figure 7. The fractal modelling of the macro-segments of the fractal poetical model of the world

As we have mentioned the fractal recursion is the process when the previous step of the fractal modelling is the starting point of the design of the next fractal step. The Mandelbrot Fractal in the fractal geometry is the starting point or the reservoir for the further fractal modelling the variety of which is identified in mathematics and the fractal geometry (e.g., (Fig. 8; Fig. 9)).

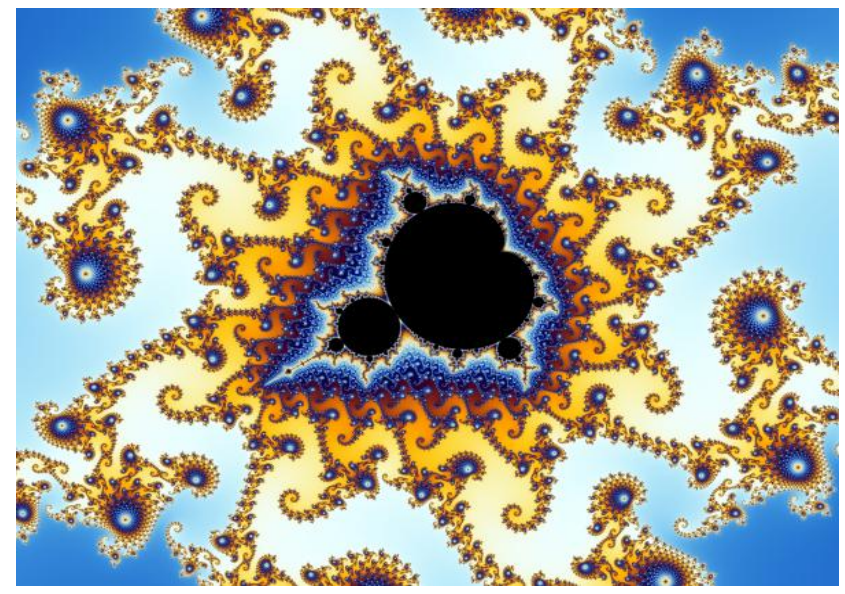

Figure 8. The computer design of various fractals from the reservoir of the Mandelbrot Fractal (after Mandelbrot 1982) 


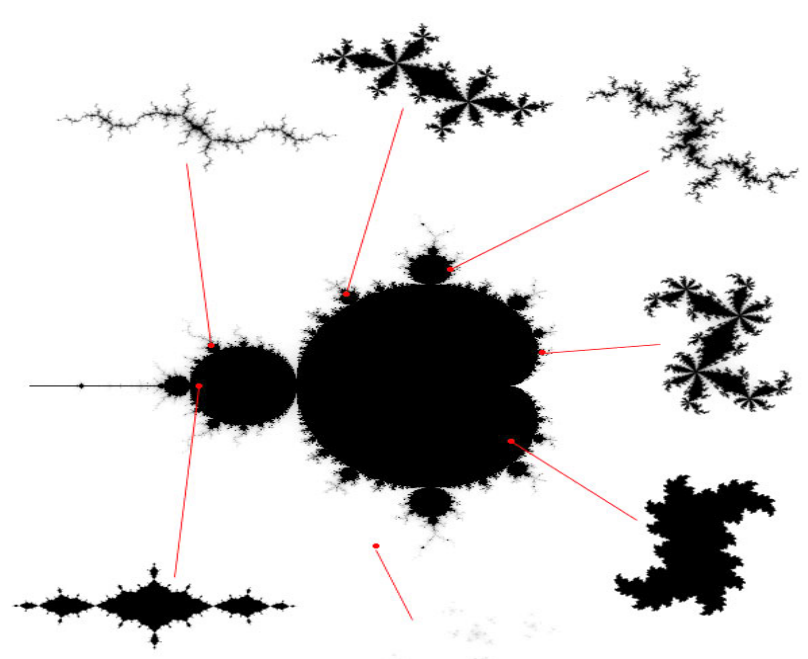

Figure 9. The modification of various fractals from the reservoir of the Mandelbrot Fractal (after Mandelbrot 1982)

In our scientific investigation the micro-segment of the fractal poetical model of the world is transformed into the segment of the conceptual senses of the frame mode fulfilled by frames. The macro-segment of the fractal poetical model of the world is transformed into the net of the conceptual senses of the integrated mode fulfilled by emergent conceptual blends. Frames and conceptual blends are modelled according to linguistic and cognitive operations and procedures existing in the cognitive linguistics and the cognitive poetics and will be presented by us in the next articles (e.g., (Fig. 10)).

The micro-segment of the fractal poetical model of the world

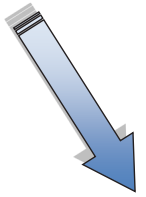

The frame mode of the fractal poetical model of the world (frames) world (conceptual blends)

Figure 10. The transformation of micro- and macro-segments of the fractal poetical model of the world into integrated modes

Graphically integrated modes will be designed by us as various types of fractals. Thus frames will be modelled as the Fractal 'Snowflake', conceptual blends - as the Fractal 'Square' (e.g., (Fig. 11)).

The fractal iteration in the process of the modelling of the fractal poetical model of the world is characterized by us as main procedures of the identification and the reconstruction of literary concepts and conceptual tropes existing in the cognitive linguistics and in the cognitive poetics. And the whole fractal poetical model of the world, consisting from micro- and macrosegments, integrated frames and conceptual blends modes will be graphically modelled as the Dragon Fractal of Harter-Heighway or the Fractal Julia and will be presented in the next scientific publications of the author (e.g., (Fig. 12))
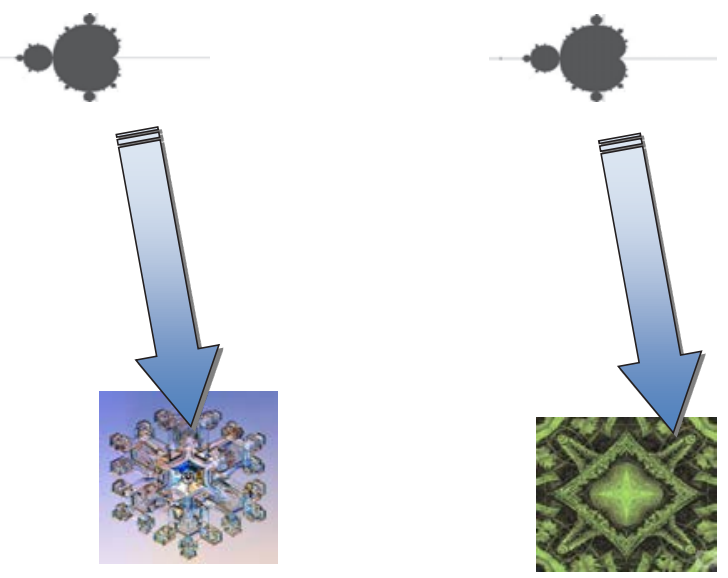

Figure 11. The graphic transformation of microand macro-segments of the fractal poetical model of the world into integrated modes

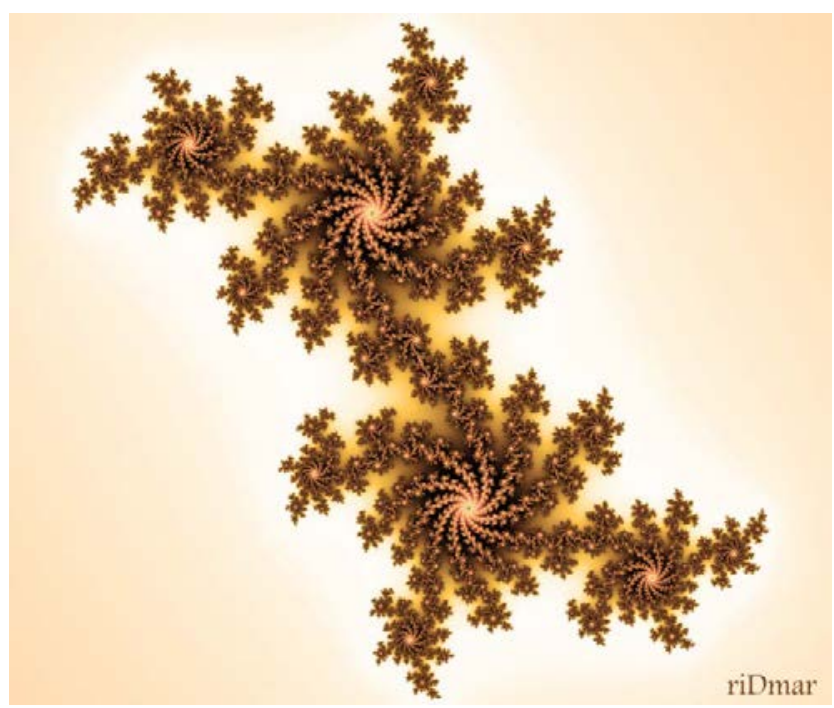

Figure 12. The Dragon Fractal of Harter-Heighway or the Fractal Julia (after Mandelbrot 1982)

In the result of the investigation of the realization of the designed fractal poetical model of the world in the British poetry of the XIX$\mathrm{XXI}^{\text {st }}$ centuries we propose the summarizing results that form the basis for the construction of the micro- and the macrosegments of the fractal poetical model of the world. As we have mentioned the microsegment of the fractal poetical model of the world is represented by the identified literary concepts in the British poetry of the XIX-XXI ${ }^{\text {st }}$ centuries. We have stated that microand macrosegments of the fractal poetical model of the world are designed by us on the basis of the Mandelbrot Fractal. Both microand macrosegments consist of tree circles, such as:

- the first main cardioid circle (the presentive and the sensual) - (1);

- the second additional circle (the conceptual and the semantic approximations) - (2); 
- the third additional circle (the semantic deviations) - (3).

Graphically both micro- and macrosegments we design according to the model of the Mandelbrot Fractal (e.g., (Fig. 13)).

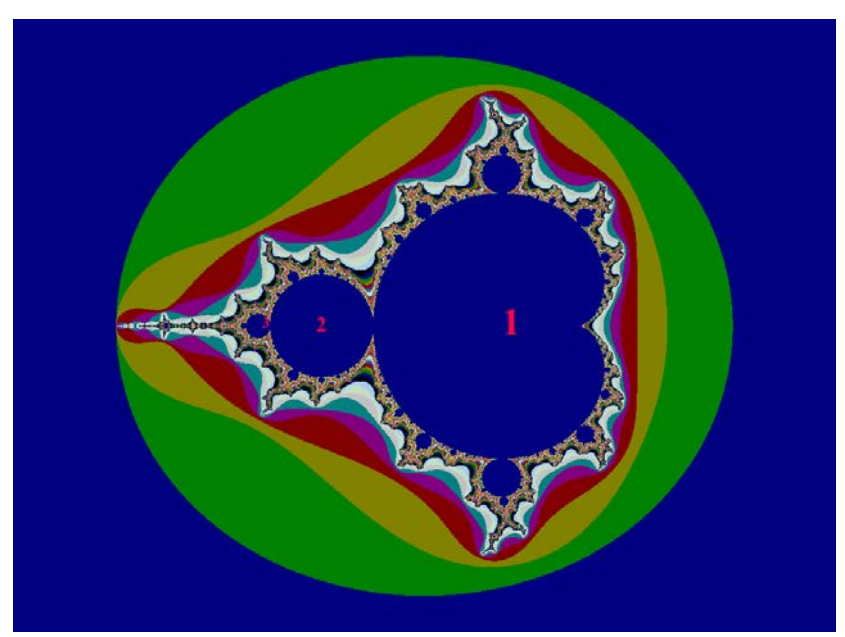

Figure 13. The graphic design of micro- and macrosegments of the fractal poetical model of the world

Conclusions. Thus, the fractal poetical model of the world is modelled by us on the basis of the British poetry of the XIX-XXI ${ }^{\text {st }}$ centuries and our investigation can be perspective because depending on the material of the investigation the fractal model of the world can be constructed not only in the poetry but in the narratology. The fractal model of the world may be mythological and religious (on the basis of religious and mythological texts), utopian (on the basis of the political texts), historical and philosophical (on the basis of historical and philosophical texts or texts that reflect the historical personality / personalities), futrological (on the basis of the texts of the fantasy genre).

Proposed fractal modelling may be perspective in the investigation of the literary work of a poet, of an author, of an epoch or poets, of authors or different cultural and historical periods. We assume that the fractal model of the world may be semiotic including symbols that can be individual and authorial, emphatic, eidetic. In the mathematics and in the geometry, in the existing fractal theory, are identified various types of fractals. It is proved that structures the algorithm of the modelling of which is changed spontaneously are superfractals. Multifractals are the complicated fractal structures that consist from several fractal structures. Allatorial fractals - fractals in which the smallest outer influence or the outer fluctuations change the form of the whole fractal.

In the linguistic perspective we consider that that the linguistic model may be superfractal segments of which are changed with the integration to the investigation of the text the comparative analysis. The multifractal is the linguistic model that is added by the other linguistic aspect (for example, the combination of the linguistic, the cognitive and the semiotic aspects of the investigation of the texts). The allatorial fractal linguistic model is the model segments of which are changed while the incorporation of new results of the investigation of the text unidentified by the predecessors.

The proposed by us methodology of the modelling of the fractal poetical model of the world opens the new paradigm in the modern cognitive linguistics and the cognitive poetics - the cognitive graphics or the cognitive fractal graphics that comprises the combination of the cognitive linguistics, of the cognitive poetics, of the mathematics, of the fractal geometry, of the theory of systems, of the synergetics. Modelled by us the fractal poetical model of the world is characterized not by the rhizome but the strictly determined structure because the fractalis characterized by the strictly determined structure and consists from the elements of the reductions scale that are self-similar and are excelled by the hierarchical organization, by the recursiveness and by the iteration because the process of the fractal modelling is determined by the multifaceted repetition of the analogical mathematical operations - iterations that are recursive, the final element of the fractal is the beginning of the new element - the recursive. Fractal iterations in our process of the design of the fractal poetical model of the world are the linguistic and the cognitive operations and mechanisms that help the linguists to identify literary concepts and to reconstruct conceptual tropes in the text. Recursiveness is the ability of the microsegment of the fractal poetical model of the world to be transformed into the frame mode, and the macrosegment - into the integrated mode of emergent conceptual blends. The cognitive fractal graphics is proved in the scientific research by the computer design of the fractal poetical model of the world on the basis of the fractal modelling in the mathematics, in the fractal geometry and in the computer graphics.

\section{References:}

1. Бистров Я.В. Біографічний наратив у лінгвокогнітивному вимірі (на матеріалі англомовної прози XX - початку XXI століть) : дис. ... д-ра філ. наук : 10.02 .04 / Київський нац. лінгвістичний ун-т. Київ, 2016. 460 с.

2. Деменок С. Л. Просто фрактал. Санкт-Петербург : Страта, 2018. $308 \mathrm{c}$.

3. Деменок С.Л. Суперфрактал. Санкт-Петербург : Страта, 2018. $228 \mathrm{c}$.

4. Москвичова О.А. Еволюція метаморфози в англійському поетичному мисленні : монографія. Херсон : Айлант, 2015. 220 c.

5. Blake W. The Selected Poems. London : Wordsworth Poetry Library, 2019. $384 \mathrm{p}$.

6. Mandelbrot B.B. The Fractal Geometry of Nature. New York : W. H. Freemanand Company, 1982. 470 p.

7. Nikonova V., Boyko Y. Gender-specific emotivity of Victorian female prose from a multidimensional perspective. In Lege artis. Language yesterday, today, tomorrow. 2019. Vol. IV (1). P. 47-82.

Москвичова О. А. Фрактальна поетична модель світу у лінгвокогнітивному висвітленні

Анотація. Екстраполюючи методологію лінгвопоетичного аналізу, методологію когнітивної лінгвістики та когнітивної поетики, враховуючи здобутки методології фрактального моделювання у математиці, фрактальній геометрії, синергетиці й теорії систем, окреслимо методику конструювання фрактальної поетичної моделі світу, яка характеризується складною структурою у лінгвокогнітивному вимірі. Вказана складність структури зумовлена когерентністю між складовими сегментами фрактальної поетичної моделі світу, тобто узгодженням дифузійних й дисипативних процесів, котрі уможливлюють когерентну зв'язність складної хаотичної структури у єдине фрактальне ціле. 3 позиції точних наук фрактальне конструювання складної моделі відбувається при когерентному об'єднанні мікроелементів складної макроструктури з синхронізацією іï еволюції. Фактором 
об'єднання складних фрактальних систем є аналогія хаосу, оскільки хаос відіграє конструктивну роль в процесі будування фрактальної моделі. У контексті дослідження під хаотичністю, важливою для конструювання фрактальної моделі світу, розуміємо лавиноподібний інвентар художніх концептів, концептів та концептуальних тропів, які можливо ідентифікувати та реконструювати на матеріалі британських поетичних текстів XIXXXI століть із застосуванням методики лінгвопоетичного, лінгвокогнітивного й поетикокогнітивного аналізів. Структурування фрактальної поетичної моделі світу у лінгвокогнітивному вимірі шляхом упорядкування художніх концептів й концептів та концептуальних тропів 3 подальшим фреймовим моделюванням та конструюванням концептуальних блендів з урахуванням методологічного інструментарію конструювання образ-схем концептуальних тропів дозволяє упорядкувати зазначені аспекти в єдиній фрактальній й лінгвокогнітивній моделі світу. У такий спосіб здійснюємо перехід когнітивної лінгвістики та когнітивної поетики на новий топологічний рівень, котрий ознаменовано можливістю графічного кодування лінгвокогнітивних постулатів у складній ієрархічній фрактальній моделі, що складається 3 самоподібних мікро- та макросегментів, а також 3 фреймової мережі та мережі концептуальних смислів.

Так, запропоноване моделювання фрактальної поетичної моделі світу відкриває нову галузь у сучасній когнітивній лінгвістиці та когнітивній поетиці з опорою на сукупність методологій точних і гуманітарних наук. Висновуємо, що такою новою ланкою постає когнітивна графіка, або, точніше, когнітивна фрактальна графіка, оскільки репрезентована методика дослідження поетичних текстів 3 подальшим конструюванням фрактальної поетичної моделі світу враховує декілька аспектів когнітивної лінгвістики, когнітивної поетики, математики, геометрії, теорії систем, синергетики.

Ключові слова: художній концепт, концептуальні тропи, фрактал, фрактальна поетична модель світу, атрактор, мікросегменти фрактальної поетичної моделі світу, макросегменти фрактальної поетичної моделі світу, мережа концептуальних смислів фреймового та інтегрованого модусів фрактальної поетичної моделі світу. 